For a given percentage of concentrate in the diet, the importance of these changes (in comparison with a normal diet) much depends on the physical form of the concentrate and of the forage, and on the level of intake. The individual differences are high, particularly when the concentrate is given ad libitum.

The butterfat content seems to be more or less closely related to these changes. In trial 2 , there was a correlation of $+0.79(\mathrm{P}<0.0 \mathrm{I})$ between the butterfat content and the proportion of acetic + butyric acids in the volatile fatty acid mixture of the rumen fluid.

\title{
INFLUENCE DU MODE DE PRÉSENTATION DES FOURRAGES DÉSHYDRATÉS SUR LA DIGESTION DANS LE RUMEN ET LE TAUX BUTYREUX DES VACHES
}

\author{
M. JOURNET \\ Station de Recherches sur l'Élevage des Ruminants, \\ Centre de Recherches de Clermont-Ferrand, I. N.R. A., \\ 63 - Saint-Genès-Champanelle
}

Les effets de la réduction en fines particules de fourrages déshydratés offerts ad libitum (graminées et luzerne) sur le comportement alimentaire (temps de consommation et de rumination) et sur la digestion dans le rumen de vaches fistulisées ont été étudiés et comparés aux effets sur le taux butyreux de vaches en lactation. Celles-ci recevaient les mêmes fourrages mais avec en plus des aliments concentrés en fonction des besoins.

Les fourrages étudiés ont été agglomérés soit dans une presse à filière, soit dans une presse à piston ; certains ont été broyés au préalable et d'autres agglomérés directement. Selon le mode de conditionnement utilisé, la taille moyenne des particules du fourrage a varié de 0,37 à $1,25 \mathrm{~mm}$ et la proportion de longues particules (> à $1,25 \mathrm{~mm}$ ) de o à $4^{8} \mathrm{p}$. Ioo.

$I^{0}$ Des liaisons étroites ont été établies sur ro échantillons de luzerne entre :

- la taille moyenne des particules de fourrage et le temps de rumination $(r=0,83)$ qui a varié de o à $34 \mathrm{p}$. Ioo đu temps total ;

- le temps de rumination et l'activité cellulolytique du jus de rumen $(r=0,95)$ qui a varié de 0,50 à 0,92 . Celle-ci est mesurée par la quantité d'un substrat cellulosique (paille d'avoine) dégradé en $48 \mathrm{~h}$ dans le rumen en utilisant la méthode des sachets de nylon. La valeur de référence est obtenue avec une ration de foin de luzerne sous forme normale;

- le temps de mastication (consommation + rumination) par $\mathrm{kg}$ de matière sèche ingérée qui a varié de I9 à 59 minutes et l'activité cellulolytique $(r=0,86)$.

$2^{3}$ Les temps de mastication ainsi que l'activité cellulolytique n'ont pas été reliés à la composition du mélange des acides gras volatils du rumen bien que celle-ci ait été légèrement différente de celle obtenue généralement avec les fourrages sous forme normale $\left[\mathrm{C}_{2} / \mathrm{C}_{3}, 3\right.$ heures après le repas $=3,6(-3,3$ à $4, \mathrm{I}) ; \mathrm{C}_{2}+\mathrm{C}_{4}+$ iso $\mathrm{C}_{4}=79, \mathrm{I}(-77,9$ à $8 \mathrm{I}, 5): 5$ luzernes et 3 graminées dont la taille moyenne des particules a varié de 0,37 à 1,25$]$. Le taux butyreux des vaches qui ont reçu ces mêmes fourrages a été légèrement réduit de $\mathrm{I}, 6 \mathrm{~g} \mathrm{p}$. I ooo $(-2,3 \mathrm{a}+\mathrm{I}, 0)$ par rapport à un régime normal, mais comme la composition des acides gras volatils, il n'a pas été relié au comportement alimentaire des animaux et à l'activité cellulolytique dans le rumen.

La distribution de fourrage grossier en faible quantité ( $\mathrm{r}$ à $2 \mathrm{~kg}$ de paille) permet d'accroître 
l'activité cellulolytique et le temps de mastication sans que ceux-ci redeviennent entièrement normaux, mais ne modifie pas la composition des AGV du rumen.

L'effet du mode de présentation des fourrages sur le comportement alimentaire, la digestion dans le rumen et la sécrétion des matières grasses du lait apparaît différent de celui des rations à base de céréales.

\section{SUMMARY}

\section{INFLUENCE OF THE PHYSICAL FORM OF DEHYDRATED FORAGES UPON DIGESTION IN THE RUMEN AND THE BUTTER FAT CONTENT OF COWS}

The effects of reducing dehydrated forages fed ad libitum (grasses and alfalfa) into fine particles upon the feeding behaviour (time of consumption and rumination) and digestion in the rumen of fistulated cows were studied and compared with the effects upon the butter fat content in lactating cows. The latter received the same forages, but also concentrates according to requirements.

The forages studied were agglomerated in two different pelleting machines (die-pellet-mill wafering-machin); some of them were previously ground and others directly agglomerated. According to the mode of processing, the mean size of the forage particles varied between 0.37 and $1.25 \mathrm{~mm}$ and the proportion of long particles $\left(>1.25 \mathrm{~mm}\right.$ ) between $\circ$ and $4^{8} \mathrm{p}$. 10o.

I0 In Io alfalfa samples, close relationships were established between :

- the mean size of the forage particles and the time of rumination $(r=0.83)$ which varied from o to 34 p. Ioo of the total time;

- the rumination time and the cellulolytic activity of the rumen fluid $(r=0.95)$ which varied from 0.50 to 0.92 . The latter was measured by the amount of oat straw degraded in 48 hours by the nylon bag method. The reference value was obtained by using a diet of alfalfa hay in the normal form;

- the mastication time (consumption + rumination) per kg dry matter intake which varied between 19 and 59 minutes and the cellulolytic activity $(r=0.86)$.

$2^{\circ}$ The time spent in masticating as well as the cellulolytic activity were not linked to the composition of the mixture of volatile fatty acids in the rumen, this composition being, however, slightly different from that generally obtained with forages in the normal form $\left[\mathrm{C}_{2} / \mathrm{C}_{3}, 3\right.$ hours after the meal $=3.6-(3.3$ to $4 . \mathrm{I}) ; \mathrm{C}_{4}+\mathrm{C}_{2}+$ iso $\mathrm{C}_{4}=79 . \mathrm{I}-(77.9$ to $8 \mathrm{I} .5): 5$ samples of alfalfa and 3 samples of grasses, the mean size of the particles of which varied from 0.37 to 1.25$]$. The butter fat content of the cows which received the same forages was slightly reduced by $1.6 \mathrm{~g}$ p. I ooo $(-2.3$ to + r.o) in comparison with a normal diet, but like the volatile fatty acid composition, the butterfat content was not related either to the feeding behaviour or to the cellulolytic activity in the rumen.

The cellulolytic activity and the mastication time may be increased by distributing low amounts of roughages ( $\mathrm{I}$ to $2 \mathrm{~kg}$ straw), but the normal values are not entirely recovered and the volatile fatty acid composition of the rumen is not changed.

The effect of physical form of forages upon the feeding behaviour, digestion in the rumen and butter fats ecretion appears to be different from that of high cereal diets. 